\title{
Decentralization of Government Functions, a European Principle of the Albanian Modernization Process: A libertarian approach to territorial issues
}

\author{
Gentian Kaprata \\ European University of Tirana
}

\section{Abstract}

Albania, for 30 years, has entered the phase of transition from a society organized into a one-party central governing regime to a democratic society of a free market economy. But the pace of moving in this direction and modernizing the country is not the expected one, because the centralized proclamations of the political elite and expertise have not allowed liberal approaches to enter Albanian legislation and governing practices. This has been the case in particular in the sector of territorial planning, where central governments have aimed and managed to not allow the actual decentralization of the governing function of drafting and adopting local territorial planning instruments. This has resulted in a shortage of local instruments, in general, but even when managed to ensure they are presented far beyond the needs, problems and objective local imbalances. This is because their distance mapping from the actual municipality for which they were designed failed to recognize the specifics and characteristics of each of them. The result has been evident; in both cases, planning has been inexistent to drive sustainable, smart and inclusive urban development processes. In this paper we aim to build another approach for future development in Albania, a country which aims at integration into the European Union. This path should be development based on previously adopted territorial planning instruments, drawn up in democratic and parliamentary processes as a local political activity. Central government must understand and accept the new and different role than the one it played 30 years ago in territorial development issues, and that the process of drafting and adopting local territorial planning instruments should be a function of local government itself.

Keywords: classical liberalism, etatism, centralism, decentralization, central government, local government, territorial strategy, local instrument of territorial planning 


\section{1-Introduction}

The issue of the separation of government functions between central government and local government is a decades-long issue in the developed countries of liberal democracy in the European Union and beyond. Decentralization of governance functions in the field of territorial planning and development is one of the basic guidelines of European Union institutions, especially for developing and transition countries such as Albania. Albania must also go on this path in its transitional, modernizing and globalizing processes, especially in line with its aspiration to integrate into the European Union. In this article, we will first briefly present a theoretical approach to the positions of the two liberal movements, left liberalism and classical liberalism, on the issues of dividing the governing scope between the two levels of governance and the process of decentralization. Further, in this article we will examine the attitude of European and world organizations, the technical expertise of territorial planning and local government, on the importance of the city as a political and autonomous entity and the issue of decentralization of functions in territorial and urban planning. We will carry out the same observation for the meetings of the Ministers responsible for the territorial and urban planning of the member states of the European Union, and its other institutions. Further, this article will continue with a brief introduction to the beginnings of decentralization and the creation of local government as a democratically and representatively created level of governance by the vote of the sovereign in the early years of the Albanian transition. In the following we will briefly present the dynamics of developments in the issue of decentralization of government functions from central government to local government, during the subsequent years of the Albanian transition. The article will proceed with an assessment of the link between decentralization of governance functions in general to the planning and territorial development sector as a very important aspect of effective governance. The article will conclude with a brief presentation of the need and necessity for a new culture, including legal regulation, in territorial planning matters and the division of planning responsibilities between the two levels of government by functions to design policies of each of them. expressed in the form of conclusions and recommendations for Albanian political and representative institutions.

\section{2- Separation of governing scope, decentralization and libertarianism}

There is a clear distinction between contemporary left-wing liberals, who often promote etatist ideas, and classical liberals who value individual freedoms as the most important political idea, even with regard to the distribution of governing functions at the two levels of government. Liberal (classical) concepts originally introduced as a rebuttal to conservatives defending a stronger state authority in social affairs. Spencer would argue, while presenting two of the most important groups in 19th-century England, the Whigs and the Tories, "Liberalism comes first as an opposition to Charles the II and his clique, their attempts to establish a monarchic 
power without any control" (Spencer, 2005, p. 16). Classical Liberals regarded decentralization as one of their essential tenets, and incorporated it into their basic governing reforms, as Spencer would note for the libertarian contribution of the Whigs in his work "On the Declaration of Reform and Local Government" (Spencer, 2005 , p. 16). Of course, Spencer could not elaborate in more detail on the libertarian principle of decentralization that had to do with the division of government functions between national and local government, because at the time he was writing cities had not received their due importance and in that sense, local government did not have the place it has today.

Aliaj in 2008 would see this concept as more than a decentralization process, when he stated, "However for a country like Albania, decentralization is only half the job of tearing down the negative effects of centralized practices inherited from the past. The full effects of decentralization would only materialize if another crucial step was taken, which is the deconcentration of power" (Aliaj, 2008, p. 128). In fact, like Spencer's broad concept, which saw the need to preserve the spaces of individual freedom from state coercion (Spencer, 2005), also the contemporary approach of Aliaj envisions, focused on the Albanian case of the third millennium, to convey the need to bring power of political decision making as close as possible to the individual. In an ideological sense, as a clear division between contemporary liberals and classical liberals, which we also call libertarians, the question of the division of governing scope between the two governing levels is addressed by Friedman. While evolution of liberal principles of the 20th century increasingly associated with the empowerment of the state in relation to the citizen are observed, another difference observed by Friedman, among liberals of the two different centuries, is that "19thcentury liberal favors political decentralization ", while "20th-century liberal favors centralized governance" (Friedman, 2005, p. 6). This underlining by Friedman would give full meaning to the ideological differences between the two types of liberals in terms of the relationship between the levels of government and the scope of each level.

19th-century liberals, or classical liberals as Friedman would call them, and libertarians in our opinion, not only believed that the scope of government activity should be limited, they also believed in the principle of decentralization. The first principle of libertarians emphasized that the main function of government should be to protect the freedom of citizens, both from enemies abroad and from their compatriots. According to libertarians (classical liberals) the main task of the state is, referring to Friedman, "to maintain law and order, to guarantee the implementation of private contracts, to promote competitive markets" (Friedman, 2005, p. 2). Beyond the first principle, classical liberals have a second principle very important in their understanding of social order and the relationship between the state and the citizen. As Friedman would put it, "The second principle is that power must be distributed. If the government is to exercise power, it is better to exercise it at the municipal level than at the state level, rather at the state level than in Washington" (Friedman, 2005, p. 3). 
If a person does not like the way a particular municipality operates, with regard to: management of sewage engineering networks, road system, public transport; or social infrastructures, such as kindergartens, preschools, schools, ambulances, hospitals; or how the city has distributed residential, employment, education areas; this man can leave this city and move on to another city that deals with these issues better and offers these public services in a better manner. Whereas in the case where these governance functions are centralized, and these sectors are treated in the same way by local government, then the situation will be the same in all municipalities, and the citizen is left to leave the country if he can (Friedman, 2005).

Preserving freedom is the main reason for reducing the governing scope and decentralizing the governance from the central government to local government, but there is also a constructive and equally valid reason. This reason tells us that centralism impedes development, as Friedman would point out, because "The great advances of mankind, whether in architecture or painting, science or literature, in industry or in agriculture, have never come from centralized governments" (Friedman, 2005, p. 2). Newton and Leibnitz, Einstein and Bohr, Shakespeare, Milton, Pasternak, Whitney, Mc Cormik, and a wide range of authorities in their knowledge that Friedman would not hesitate to emphasize "none of them opened new horizons for human knowledge and culture in response to government directives" (Friedman, 2005, p. 4). And in fact, all of humanity's greatest achievements came from individual genius, from the approaches and views advocated by minority groups; but at a time of a social climate that allowed for the diversity and multiplicity that proclaims and implements decentralization.

When it comes to multi-level governance, and the advantages of a decentralized system of government over centralized governance - and to use an Aliaj term of concentrated governance - the positive impact that central government can have is not excluded or denied. But, as Friedman would point out, "Government can never reproduce the diversity and multiplicity of individual action" (Friedman, 2005, p. 4), and in this sense, no central government can address the important local issues that arise in a variety of human, social, cultural and geographical specificities and characteristics, except in uniformity. A government can greatly regulate and improve the standard of living of many citizens in many local areas or cities of the country, and perhaps even the whole country as an average, if it imposes standard conditions on housing, food or clothing, or by imposing standard norms on education, road building, or hygiene and the environment. But, as Friedman would point out, "during this process the government replaces progress with stalemate, offering uniform mediocrity rather than diversity which is so essential to experimentation that it can make tomorrow's last stand above today's average " (Friedman, 2005, p. 4). Therefore, what we need more than ever is to seek and implement decentralization practices to build more capable individuals for the future, and better living centers, than what we have today. 


\section{3- The importance of the city and the decentralization to the technical and local institutions of the countries of liberal democracy}

Following the major political changes of 1990-1992, which paved the way for Albania's transition from a socialist country of centrally planned economy to a country of liberal democracy and a free market economy, many liberalization reforms were undertaken with the aim of achieving political and economic similarities with Western countries (Biberaj, 2000; Fuga, 2003, 2004; Lami 2013).

Through the reforms designed and implemented during 1992-1996, the first phase of the territorial governance paved the way for the main goal Albanians expressed in the anti-communist protests of "Albania as all Europe" (Meksi, 1992, 2019). Since then, the country has been involved in a process of integration into the European Union, presented in a number of different sectors of country's life and society (Gjuraj, 2015; Biberaj, 2000, Lami, 2013). One of the essential aspects where the country has a need to strive for resemblance with the EU member states is the place and importance that these countries have given in the past, give today and promote for the future, the role of local government.

Albania's communist past of 1944-1991 obstructs this aim of Albanian society, especially in the sector of territorial government. Although a number of reforms have been carried out in the area of planning and territorial development, the etatist mentality that has accompanied political thinking and sectoral expertise, as Aliaj would distinguish, is "the almost conservative mindset of professionals who still fail to emerge today, above the limitations of the mentality and education of the period of the centralized economy "(Aliaj, 2008, p. 96), has not allowed the local dimension of territorial governance and local democracy to be strengthened. The European Union, where a vast majority of Albanians want to integrate to, attaches particular importance to the city as a political entity, to local autonomy and local democracy. We will try to address this in three main political pillars, the dimension of EU local governments, the national governments dimension of EU member states, and the dimension of professionals, technicians and researchers in the field of territorial development and urban from all over the world, starting with the latter.

One of the most important documents on a global scale is the 'Vancouver Declaration' adopted at the 2006 World Planners Congress held in Vancouver, Canada. The statement was signed by 29 leaders of the world's largest institutes and agencies. The essence of this statement was to establish some basic principles of urban and territorial planning globally, where the principle of planning at the governmental level was most essential. According to this statement, the types of planning instruments had to be consistent with the level of governance that drafted and approved these instruments. The political and technical worlds had to recognize that just as there are strategic plans that require the authority of national governments to be drafted and adopted, there are also local plans that must be carried out and approved by local government because of the cultural and territorial specificities and 
diversity that different cities represent, as would be stated in the statement "Planning is strategic and local, integrative, participatory, creative, representative of cultural diversity and supports equality issues" (WPC, 2006).

Governance-level planning emphasis is placed on all documents with political approaches of world and European planners, including, but not limited to, the Congress for the New Urbanism in their document 'The Charter of New Urbanism' (CNU, 1996) and the European Council of Town Planners, in 'The New Athens Charter 2003; Vision for 21st Century Cities', adopted in Lisbon in 2003 (ECTP, 2003). But we can also mention the European Conference 'Urban Future' in Saarbrucken, Germany, which brought together key players of the URBAN Community Initiative at local, regional, national and European levels. With approximately 300 participants from 22 member countries, the added value of the 'Acquis URBAN' document was discussed at the conference, and its core principles were presented and discussed. This document was accompanied by a joint statement to be presented to Mrs. Danuta Hubner, EU Commissioner for Regional Policy, but also other European and local politicians and decision makers of the member countries. As stated, inter alia, in the statement "Through the important role and potential of cities for regional development and the cohesion of EU territory on the one hand, and the prevailing problems of urban areas on the other, in the upcoming period many cities will benefit from EU funding and to a longer extent" (EC, 2005), the importance of cities and local planning in European processes, including funding from European Basis projects, becomes very clear.

The importance of cities, territorial planning in the local dimension and local democracy to the European Union is also demonstrated by the place that is given to it, the political statements and attitudes of local authorities. The European Commission supported the initiative of 80 European local authorities and 253 representatives of international organizations, member governments, scientific and consulting institutions to hold the European Conference on Sustainable Development. This Conference took place in Aalborg, Denmark, in May 1994 and drafted and agreed the 'Aalborg Charter'. The essence of this statement was the importance of cities as clear political entities, as it states "We, the European cities, the signatories of this charter, declare that throughout history, our cities have existed and challenged empires, nation states, and regimes and survived as centers of social life, carriers of economies, and guardians of culture, heritage and traditions. Together with families and neighbors, cities have been fundamental elements of our states and societies" (EC, 1994).

The charter was discussed by more than 600 participants in 36 Aalborg Conference seminars, and aimed to highlight cities' self-government skills, as it would underline "We, the cities, are aware that we have the skills, knowledge and creative potential to furthering sustainable lifestyles and designing and managing our cities towards sustainability" (EC, 1994). One of the highlights of the Aalborg Charter was the representative dimension of the sovereignty of local authorities, as it presented "As democratically elected representatives of our communities, we are able to take 
responsibility for reshaping our cities towards sustainability" (EC, 1994). Therefore, what this massive conference participants and other local actors who have been joining them for years through the signature of this charter demanded became very clear from the statement "The extent to which our cities are capable of answering to this challenge depends on the granting of rights to local self-government, in accordance with the principle of dependency. It is essential that the local government be given sufficient powers and provided with sustainable financial basis" (EC, 1994). The Aalborg Conference put forward the demand for the continued expansion of local government functions and local self-government, a requirement that is repeated in the dynamics of decentralization of government functions to this day. This conference has become periodical, every three years, to support the same decentralized approach and to support local democracy.

\section{4- The importance of the city and decentralization to European Union institutions}

The European Union supports the decentralization and reinforcement of the cities' roles in governance also directly, through its initiatives. In this regard, we will first bring up the Ministerial Meeting on Territorial Cohesion, held in Rotterdam, the Netherlands on 29 November 2004. In this meeting the Ministers of the EU Member States responsible for territorial development issues shared among them the experiences of different European countries in urban policy in recent decades and identified and generated a set of common principles that frame what they considered to be successful policies. Ministers of EU member states adopted a joint document entitled 'Urban Acquis', which provides the foundations for developing a more coherent urban policy approach to the future. 'Urban Acquis' prioritized, among other things, the emphasis on the importance of planning at the governing level by prioritizing 'Cities must be livable, places of alternative and cultural identity' (EU, 2004), through which it recognized the need to identify and utilize the specifics and characteristics of each city as a way of developing in cohesion. The document outlined the mechanisms for successful urban policy, which emphasized "Sectoral, regional and local policies should be better integrated" (EU, 2004), recognizing the particular role of cities in territorial policies. It presented interested parties engagements highlighting inter alia "Public, private and community partners in cities should engage in constructive working relationships. The partnership must balance the democratic responsibilities of elected local government" (EU, 2004), and seek to achieve the right spatial balance and encourage good practices, study of policies and capacities.

In this sense, the Leipzig Ministerial can also be mentioned, which produced the 'Leipzig Charter for Sustainable European Cities', held on May 24-25, 2007 in the German city from which it was named. This Charter underlined, as its essence, "In recognition of the chances and opportunities as well as of the different historical, economic, social and environmental pasts of European cities, the Ministers of Member States responsible for Urban Development agreed on common principles" (EU, 2007), 
and in this sense reflected the importance of the different specifics of the different cities of the EU member states, accepting only common policy principles and strategies. The charter gave a special place to the polycentric dimension of development, when EU member states' ministers committed themselves to promoting balanced territorial development based on "the polycentric urban structure of Europe" (EU, 2007). The document further stated that ministers responsible for urban development in EU member states "consider European cities of all measures that have evolved in history to be valuable and irreplaceable economic, social and cultural assets" (EU, 2007).

From 2007 onwards, various documents have been agreed upon at various political levels, with many documents highlighting the importance of city, local autonomy and local democracy, to name only the two most important as' Spatial Planning; Key Instrument for Development and Effective Governance with Special Reference to Countries in Transition' of the United Nations Economic Commission for Europe (UNECE, 2008), and the 'Territorial Agenda 2020, towards a Comprehensive, Smart and Sustainable Europe of Different Regions', agreed at the Ministerial Informal with Ministers responsible for Spatial Planning and Territorial Development on 19 May 2011 in Godollo, Hungary (EU, 2010). These documents and others we touched upon earlier were the beginnings of a long process which will continue in the future, especially in developing countries such as Albania, which are indispensable in taking steps in this very important direction of democracy and development.

\section{5- The beginnings of decentralization in transitional Albania}

The profound centralization of governing functions was one of the characteristics of the 46-year-old socialist regime that the territorial governments of transition had to face (Meksi, 1992, 2019). This was not a simple task, because the 46-year-old tradition did not allow for a profound reform, while at the same time producing acceptable results on the ground. The central authorities' unilateral political decisionmaking for a deep reform to decentralize the distribution of government functions, as in many other areas of the economic sector in particular, would not have a tangible result if it were not supported by other actors that would implement it. As Aliaj would point out "In fact, if we study the history of governance in Albania, we will notice a handicap that has been created during the years of the centralized economy and which remains silent today. This obstacle is about concentration, one of the most sophisticated forms of centralization of power in Albania during the years of communist dictatorship" (Aliaj, 2008, p. 130). In this sense, the process of decentralization in the early years of transition was not an easy one, due to the concentrated and centralized mindset of the society and especially the experts and officials involved in the implementation process of this potential reform on the ground.

During the first years of transition there was a need to take action to strengthen local government units in the context of administrative reform. These needs, defined in the 1992-1996 government program, consisted of two main points. First, there was the 
necessity of holding pluralistic elections for the local level of government likewise. The transition from a Labor Party-led government, the only party that had led a communist regime for 46 years to the Democratic Party, as the first opposition party, necessitated pluralist elections at the local government level as well. As Meksi, in his 1992-1996 government program, which he led would point out, "Administrative reforms and quality improvements must also be carried out at the local level so that the central government's economic policy can be implemented nationwide. We will take measures to hold local elections within a few months" (Meksi, 1992; 2019). With this clear aim based on the principles of classical liberalism, the Meksi government also broke the first taboo on local government authority, which was exalted from a chain of the Party-State system, where the Chairman of the District Executive Committee was nominated by the Labor Party; to a democratic and pluralistic institution where the mayor was elected by the votes of the citizens of the municipality.

The Meksi Government, 1992-1996, prepared and adopted Law no. 7573, dt. 16. 6. 1992 'On the Elections of Local Government Bodies' which paved the way for local democracy. In accordance with Article 1 of this law "Local Government Bodies are elected by general, direct, secret and free vote" (Official Journal, 1992, No. 3), which paved the way for a complete democratization of political life. Through this law, the territorial governance of the first phase also paved the way for the creation of the first local parliaments, in accordance with its Article 1 "The Election of Local Councils is rendered by a proportional system with multi-names lists" but also gave a deep dimension representing the mayor and the head of the municipality of a residential center, municipality or commune, in accordance with Article 1 of this Law "The mayors of communes and municipalities are elected by a majoritarian system in areas with a nominal list" (Official Journal, 1992, no. 3). The context of this law laid the groundwork for what Fuga in 2012 would call discursive democracy and define as "Discursive democracy is defined at the level when the interested public speaks and listens to community problems and on this basis creates a kind of common opinion on policies to be followed and local government teams that can best implement them" (Fuga, 2012, p. 74).

The second issue, dealt by the 1992-1996 Democratic Party government program in relation to local government, was aimed at empowering local government units by fully reforming their role and responsibilities, as Meksi would state "At the same time we will propose to Parliament to consider the requirement to redefine the role and responsibilities of local bodies, including fiscal matters, as well as their administrative and legal relations with the central government "(Meksi, 1992, 2019). This was the second step the Meksi government took in creating and strengthening local democracy, which required a clear separation between the two levels of government and their roles in social affairs. As Cili would point out, "the Meksi government made major and bold reforms in the first phase" to emphasize also the Meksi government's struggle against the deep centralization of the communist regime "removed many of the economic institutions and practices centralized state had left behind." (Çili, 2013, p. 
42). Meksi turned the issue of defining an important role of local government in Albania in the early years of transition to a key issue, as he would express himself in the speech held in the Albanian Parliament for the presentation of the Governing Program, 1992-1996 "Without local administrative and democratic reform, our political and economic revolution will not be complete" (Meksi, 1992; 2019).

\section{6- The dynamics and deceleration of decentralization in Transitional Albania}

However, decentralization did not go at the required speed, due to the frequent blockade by the Socialist Party, which was the successor of the Labor Party that had ruled the country for 46 years under the centralist inspiration of Party-State ideology, as HIS Alumni et al., would express "although central authorities have initiated a process of decentralization towards local government, this process is practically frozen for political reasons" (HIS Alumni et al., 1998, p. 103). The decentralization process received a second impetus by the end of the nineties. During 1998-2000, the country formally ratified the European Charter of Local Self-Government, embodied its core principles in the new Constitution, and adopted legal reforms for local selfgovernment (WB, 2004). As the World Bank would point out in its report 'Albania: Decentralization in Transition', important institutional adjustments have been made over the years, regulations have been adopted. "These actions include: (i) establishing a National (Inter-Ministerial) Committee on Decentralization (NCD), supported by the Technical Expert Group with international expertise on Decentralization (GED); (ii) the adoption of the National Decentralization Autonomy Strategy by the National Committee on Decentralization (NCD); (iii) the adoption of a new law on the role of Prefects and their relationship with local authorities; (iv) the adoption of the Law on State Real Estate, the Law on Transfer of State Assets to Local Authorities, and the establishment of the Agency for the Inventory and Transfer of Public Assets; (v) the transfer of some specific key functions to local authorities" (WB, 2004).

In order to focus on policies related to the territory and its administration, it was during this period that territorial reform was concretized by law no. 8652, dt. 31.07.2000 'On the organization and functioning of local government', promulgated by Decree No. 2729, dated 7.8.2000 of the President of the Republic of Albania, Rexhep Meidani (QKB, 2018). This reform and this law did not affect the concept of geographical division and territorial extension of local government units, which referred to point 4, article 5, of Chapter II of law no. 8652, dt. 31.07.2000 'On the organization and functioning of local government' was conceived in three types. Referring to point 4 of Article 5 of Chapter II of Law no. 8652, dt. 31.07.2000 'On the organization and functioning of local government' they were: district, second level local government and municipality and commune, basic local government units $(\mathrm{QKB}$, 2018). Together with law no. $8653 / 2000$ 'On the administrative-territorial division of local government units in the Republic of Albania' marked the end of the previous District Councils, thereby diminishing the direct political influence of the state on local government activities. It was clear that this created a stable legal framework that 
would enable decentralized administrative and fiscal structures to function, involving self-governing circles, municipalities and communes (WB, 2004).

The contribution of this primary legislation was to the concept of the principle of subsidiarity and the process of decentralization, as the World Bank would say "Although Albania is far from completing the political, administrative and fiscal decentralization picture that could satisfactorily improve distribution in terms of services, governance and accountability, it must be acknowledged that considerable progress has been made in building institutions and the basic legal framework, as well as in implementing policies towards decentralization " (WB, 2004). Local Government Units, at both levels: district and municipality / commune, were assigned several governance functions which were grouped: (i) delegated functions, (ii) shared functions and (iii) specific functions, referred to in section 2, of Chapter I of Law no. 8652, dt. 31.07.2000 'On the organization and functioning of local government' (QKB, 2018). This law also referred to point 5c, of Article 72 of Chapter XI, municipalities and communes also had the power of urban planning, land management and social housing, including the approval of construction sites and the granting building permits, which began as of January 1, 2001 (QKB, 2018). However, as we will show further, the function of urban planning, namely the design and adoption of territorial planning instruments, came under the control of central government, which, through the National Territorial Adjustment Council, and subsequently the National Council of Territory, which consisted of the Prime Minister and some ministers, had to make the final approval of these local planning instruments.

Although through this reform local government was given some functions in matters of territorial planning and territorial control of construction and social and housing permits, they did not meet the realistic expectations and needs for decentralization. As Aliaj would point out, "the last decade has been a lot of talk about decentralization. After a successful start in drafting the reform, the latter has moved at a very slow pace, largely due to a lack of political will, despite some efforts by the line minister to cover territorial, environmental and tourism planning issues." (Aliaj, 2008, p. 128) The fourth phase of territorial governance, 2013-2020, undertook a profound reform of administrative and territorial affairs, through law no. 115/2014 'On the administrative-territorial division of local government units in the Republic of Albania' and Law no. 139/2015 'On Local Self-Governance' (QKB, 2018). This reform, as we shall see in this paper, damaged local democracy in two ways, first by removing the citizen-voted politician and replacing him with the politically appointed administrator, and secondly by reducing the functions of Local Government Units, as Fuga would say of this reform, "It is strange that this process of centralization and administrative concentration and homogenization of local government and territory after 2014 came with a decentralization propaganda" and further on the same page to declare "The local democracy in Albania after this [Reform] no longer exists!" (Fuga, 2019, p. 224). 


\section{7- Local democracy and territory planning and development}

One of the aspects where local democracy can be better, more clearly and more productively expressed in enhancing the quality of life of communities, families and individuals is the sector of territorial development and planning. For territorial and urban issues, what we need to understand and agree upon from the outset is the fact that the role of governing institutions is inevitable. In the planning and decisionmaking processes for control of territorial development issues, the involvement of state institutions is necessary (UN, 1976). Referring to Friedman, though he is often seen as opposed to the idea of the state, he rather recognizes his need, as he points out "Rather, governance is essential, at the same time as a forum for determining the rules of the game and as an arbitrator, to interpret and impose the application of previously established rules" (Friedman, 2005, p. 17). Urban planning means the compromise of all interested parties involved or affected by planning in a given territory, and in this sense, the role of the organizer and moderator in the processes of convening those groups and interests, of government institutions is necessary (HIS Alumni et al., 1998; Aliaj, 2008, Fuga, 2012).

But even if we refer to Spencer, while answering the question what purposes all people would agree to cooperate on, he would point out, among other things, that "Another kind of cooperation that all people are interested in, is the use of the territory in which they reside" (Spencer, 2005, p. 78). This cooperation is very important, first of all, to give a common understanding of land uses, but also to ensure the contributions of all owners to shared social spaces and infrastructures, or as stated by Spencer "quite rightly, the decisions of the majority would prevail over the conditions in which part of the land would be used respectively to provide food, to build traffic, or for other purposes" (Spencer, 2005, p. 78). Translated into the language of urban and territorial development, this Spencer statement means functional zoning, or defining land use and building zones in it (IHS Alumni, IHS and Co-Plan, 1998; Aliaj, 2008). Whereas on matters of territorial control, such as building permits, control of territory for informal construction and decision-making in cases where the territory is affected by illegal construction, the role of state institutions is indispensable (IHS Alumni et al., 1998).

The real issue at stake is: who in government, central or local government, will have the function of its own governor to design local instruments of territorial planning and development. The practices of the European Union member states are numerous and show us, not only in the theoretical dimension or political agreements, but also in the life practices that the decentralization of governance functions significantly affects the functioning of the city and has positive implications for the quality of life of citizens. As Aliaj would mention a case where decentralization works "In France, Montpellier is a typical case of urban decentralization. By 1980, this town was more of a large Mediterranean village". But the railroad was enough and the implementation of a fast train turned the attention of Parisians, who began to buy villas and especially 
the city administration that started investing in leisure and entertainment venues, and "The result is the creation of a city and a cosmopolitan society that are completely different from those of a few years ago" (Aliaj, 2008, p. 117).

Decentralization is particularly important for those governance functions related to the administration of local territory, as the example presented by Aliaj shows. While the administration of local affairs would have no productivity if it was carried out before planning (HIS Alumni et al., 1998) and that this planning had not been carried out by governing authorities that would implement concrete actions on the territory that were determined by planning, to be accomplished. Technical and independent expertise has often raised this concern, as Aliaj would point out: "What will be the shortest fate and way to end the stall of the decentralization process in order to prevent centralized abuses and individual monopolies in the sphere of planning and administration of the territory forever" (Aliaj, 2008, p. 100).

The issue of decentralization of governance functions related to territorial and urban development and planning has been one of the most discussed issues in recent years, as would be emphasized by HIS Alumni, HIS and Co-Plan "The degree of local independence has been the object the discussion in Albania after the political changes (1991), but with no concrete results. The idea of establishing new relations between central and local government is based on the decentralization of competencies" (HIS Alumni et al., 1998, p. 31). But the reality has proved that the products are lacking, and the first reason being the etatist approach and the particularly centralized one has dominated professional thinking and technical and administrative expertise in these transition years (Aliaj, 2008). Even when various experts have expressed aspirations for decentralization, through assessments, such as HIS Alumni et al., "the role of local government is currently very reduced while local government intervention is very large" (HIS Alumni, et al., 1998, p. 31), they have failed to be considered by lawmaking authorities, or, as we shall note in the following, even where implemented by legislation, the decentralization process has rapidly turned back.

\section{8- The centralized approach of the Albanian transition governments}

The Albanian governments of transition have introduced an etatist and concentric approach to territorial planning. This can be easily discerned if we observe the legislation that they have drafted and further adopted in the Assembly of the Republic of Albania in these years. As HIS Alumni et al., would point out "At present, urban legislation, in the face of the alternative to open the way to capacity building at the local level, seems to have chosen the centralization of competences in the field of planning" (HIS Alumni et al., 1998, p. 32). In regards to the territorial development four laws were adopted in the Albanian Parliament in the period 1993-2014: Law 7693/1993 'On Urban Planning' (QKB, 2010); law 8405/1998 'On Urban Planning' (QBZ, 2010); Law 10119/2009 'On Territorial Planning and Development' (QBZ, 2019); Law no. 107/2014 'On Territory Planning and Development' (QBZ, 2019). These laws have undergone repeated and consistent changes, notably the Law 8405/1998 'On Urban 
Planning' was amended ten times and Law 10119/2009 'On Territorial Planning and Development' was amended few months after its adoption, before the entry into full force, by Law no. 10 258, dated 25.3.2010 'On some additions and amendments to Law no. 10119, dated 23 April 2009' On Territorial Planning ' (QKB, 2010). 'Hyperlegislation', as Spencer would define the layout and frequent changes of legislation (Spencer, 2005), characterized the transition governance in the field of territorial development.

These amendments, in particular through Law No. 10 258, dated 25.3.2010 'On some additions and amendments to Law No 10 119, dated 23 April 2009' On Territorial Planning ', consisted in strengthening the role of the central government. The National Territorial Council, which is a national planning authority, headed by the Prime Minister and composed of several ministers, was granted the right to final approval of local planning instruments, as noted in Article 2 and Article 3 thereof, (QKB, 2010). This was a clear case but not the only one, in which the central government, using its majority in the Albanian Parliament, works to reverse the process of decentralization of government functions. This is because according to the original Law No. 10119, dated 23.4.2009 'On Territorial Planning', specifically Article 13 (2a), local government units had the function of approving local territorial planning instruments for the territory under their jurisdiction, while the National Territorial Council was only authorized to formally approve the compatibility of the local instrument with the national instruments. Law no. 10 258, dated 25.3.2010 returns the hierarchical concept of municipalities, as noted in point 3 of Article 3, considering some municipalities as First Category (QKB, 2010). This, with the intention of the National Territorial Council exercising in some local government units, an even deeper political control. Other than this 2009 attempt reversed a few months later, all other laws have not delegated to the Local Government the right to design and approve local territorial planning instruments within the limits of their jurisdiction.

The fourth phase territorial governance undertook a program to draft general local plans of the 61 municipalities of the Republic. This program has been going on for years and now 38 Local Government Units have a legally approved planning instrument, while the rest is in the process of drafting or approving this instrument (AKPT 2015-2020). It is clear that this action, albeit driven by the positive inclination of the central government, is an action with a "paternalistic approach" (Friedman, 2005 ) that harms the local autonomy of local government. Undoubtedly, as we have often mentioned in this paper, the need to develop territorial planning instruments, especially in the local dimension, is a necessity, but central government intervention in a basic function and duty pertaining to central government is a wrong governing act, for many reasons.

First, it undermines democracy and the principle of proportionality, according to which urban problems and imbalances must be dealt with at the level they appear, as UNECE would emphasize "The principle [of proportionality] is this, it is not necessary" 
to use a reference to break a peanut if I can make a peanut-breaker. 'In other words, the ways should be in proportion to the conclusions." (UNECE, 2008). This project of the central government brought great damage to the process of modernizing governance, as one of the basic methods to increase local autonomy and strengthen local institutions. But most importantly, for this part of the paper, by concentrating the project on the National Territorial Planning Agency, which is an institution subordinate to the Prime Minister, it removed this project from the city government administrations for which each of these instruments is being drafted. Whereas, as Aliaj would say, "The full realization of this reform is now an urgent necessity to remedy the mischievous way in which control over the country's financial and material resources is exercised, and above all to correct unfair and clientelist distribution of these resources, based on the situation and conditions created especially due to the population movement and the dynamic process of urbanization" (Aliaj, 2008, p. 128), there is a need for a deep and perpetual decentralization to this sector.

\section{Conclusions and recommendations}

Territorial governance (the governing sector dealing with territorial issues), although Albania has been aiming for 30 years to move away from socialist modes of development based on central planning, towards development based on an inclusive free market economy, this social goal has not been introduced into legislation and in governing and administrative practices. Local territorial planning instruments have been considered by central governments, which have drafted sectoral legislation, as one of their domains. Albania's territorial governance, during these 30 years of transition, should have been inspired by the libertarian approaches introduced by the classics of classical liberal thought and by the European Union's demands for a proportionate division of government functions in relation to territorial planning. Although the sovereign's stated political intent has been clear: to accelerate integration into the European Union by adopting its principles, and to follow the guidelines given to member states or in the integration processes towards it, and in particular good practices that come from its member countries; yet it seems that the Albanian transitional governments have not followed this path required by the sovereign.

The best approach is one that is based on the 'own functions' of each level of government, as set out in the respective laws for the organization and functioning of each level of government. Central government should focus only on the development and adoption of territorial planning instruments in relation to those development sectors for which policies are drafted, such as national air transport infrastructure policies, maritime, rail and national road axes, and to balance the population. across national territory. For specific issues, and for territories of national importance in planning, the central government should have the power to intervene, but even in these cases the national importance of the issue of territory should be argued, with a view to avoiding centralized practices. 
The design and approval of local planning instruments should be the full competence of local government units for the territory in their jurisdiction. Such a space of local freedom would allow the perspective development of local units to be oriented to the territorial and cultural specificity of each city separately. It would also allow cities to focus on and prioritize the needs that they themselves would prioritize for their future. The product of this decentralized approach would be the basis for creating a variety and diversity of Albanian cities, which would be served by its specifics to compete for freedom to absorb as many residents and businesses as possible.

Development based on the natural, territorial, cultural and social specifics and characteristics, creates a wide range of possibilities for citizens to choose the city they like most to live, work and invest. The variety and diversity of cities, by type of development, would also serve the regional dimension, because cities with different developmental physiognomies create complementary relationships between them and form polycentric urban areas, which are a very important European approach. Also, this approach has great benefits in the overall national dimension, because it enables the activation of all the country's natural and territorial resources and produces a synergy of overall national development that is greater than the sum of the economies of each city in the country.

As a final recommendation, we ask the Parliament of the Republic of Albania to ask the Council of Ministers or through its internal mechanisms to draft a new legal basis for territorial planning, with particular emphasis being given to planning at every governmental level. In this new legal basis, there should be a clear distinction of who are the territorial planning authorities, the territorial planning instruments, and who is the authority that drafts and approves each of the types of territorial planning instruments. This division should coincide with the functions that the levels of government, both central and local, have in drafting sectoral policies and their jurisdiction over the territory, with a clear decentralized approach.

\section{Bibliography}

[1] Agjensia Kombëtare e Planifikimit të Territorit, [AKPT], (2015-2020), 'Plane të Përgjithshme Vendore' http://planifikimi.gov.al/index.php?id=732

[2] Aliaj, B., (2008), 'Misteri i Gjashtë', Tiranë: shtëpia botuese Botime Afrojdit,

[3] Banka Botërore, [BB], (2004), 'Shqipëria: Decentralizimi në Tranzicion' http://siteresources.worldbank.org/INTALBANIA/Resources/Decentralizi miNeTranzicionV1.pdf

[4] Banka Botërore, [BB], (2007), 'Shqipëria: Zhvillimi Urban, Migrimi dhe Ulja e Varfërisë', Tiranë, http://documents.worldbank.org/curated/en/547941468004218271/pdf /400710ESW0P0961Dec0310200701public1.pdf

[5] Biberaj, E., (2000), 'Shqipëria në Tranzicion; Rruga e vështirë drejt demokracisë', Tiranë: botimet Ora

[6] Çili H., (2013), 'Kundër-Reforma', Tiranë: Shtëpia Botuese UET Pres, 
[7] Congres for the New Urbanism, [CNU], (1996), 'Charter of the New Urbanism' , Vankuver, Kanada https://www.cnu.org/who-we-are/charternew-urbanism

[8] European Commission, [EC], (1994), 'Charter of European Cities \& Towns Towards Sustainability', Aalborg Denmark https://sustainablecities.eu/fileadmin/repository/Aalborg_Charter/Aalbo rg_Charter_English.pdf

[9] European Commission, [EC], (2005), 'Acquis Urban; Using Cities' Best Practises for European Cohesion Policy Common Declaration of URBAN cities and players at the European Conference "URBAN Future" on June 8th and 9th, 2005 in Saarbrücken (Germany)

https://ec.europa.eu/regional_policy/archive/newsroom/document/pdf/s aarbrucken_urban_en.pdf

[10] European Union, [EU], (2007), 'LEIPZIG CHARTER on Sustainable European Cities, Leipzig

https://ec.europa.eu/regional_policy/archive/themes/urban/leipzig_chart er.pdf

[11] European Union, [EU], (2004) , 'Urban Acquis' Ministerial Meeting on Territorial Cohesion on 29 November 2004 in Rotterdam https://ec.europa.eu/commission/presscorner/detail/en/MEMO_04_278

[12] European Union, [EU], (2010), 'Territorial Agenda of the European Union $2020^{\prime}$

https://ec.europa.eu/regional_policy/en/information/publications/comm unications/2011/territorial-agenda-of-the-european-union-2020

[13] Europian Council of Town Planners, [ECTP], (2003) 'The New Charter of Athens 2003; Vision for Cities in the 21st century', Lisbon http://www.ceuectp.eu/images/stories/download/charter2003.pdf

[14] Fletore Zyrtare, (1992), 'Ligj për Zgjedhjet e Organeve të Pushtetit Vendor, $n r .7573$, dt. 16. 6. 1992', Qëndra e Botimeve Zyrtare, Fletore Zyrtare, Nr. 3

[15] Friedman M., (1962), 'Kapitalizmi dhe Liria', Tiranë: shtëpia botuese IPLS dhe Dita, përkthim nga Adri Nurellari, 2005

[16] Fuga, A., (2003), 'Majtaj jo djathtas', Tiranë: Botime Ora,

[17] Fuga, A., (2004), 'Shoqëria periferike', Tiranë: Botime Ora,

[18] Fuga A., (2012), 'Rënia e Qytetit', Tiranë: shtëpia botuese Papirus,

[19] Gjura Tonin, (2015), 'Nova Demokratia', Tiranë: shtëpia botuese UET press

[20] IHS Alumni, IHS, Co-Plan, (1998), 'Qyteti i ndërtuar nga njerëzit; Ide për të menaxhuar realitetin urban në Shqipëri', Shtëpia Botuese Eurorilindja, Tiranë

[21] Meijers E., (2007), 'Synergy in Polycentric Urban Regions Complementarity, organizing capacity and critical mass', IOS Press.

[22] Meksi A., (1992), 'Programi i Qeverisë së Aleksandër Meksit, 1992-1996', Tiranë http://shtetiweb.org/2015/09/13/programi-qeverise-aleksandermeksi-1992-1996/ 
[23] Meksi A., (2019), 'Fjalime në Kuvendin e Shqipërisë', Tiranë: Shërbimi i Botimeve Parlamentare,

[24] Lami, R., (2013), 'Paqartësia e strukturimit të raporteve; Parti PolitikeIdeologji', Tiranë: Universiteti i Tiranës, Fakulteti i Shkencave Sociale, Departamenti i Sociologjisë , Programi i Studimit të Doktoraturës http://www.doktoratura.unitir.edu.al/wpcontent/uploads/2013/12/Doktorature-Roland-Lami-Fakulteti-iShkencave-Sociale-Departamenti-i-Sociologjise.pdf

[25] QBZ (2010), 'Përmbledhëse Legjislacioni për Ndërtimet', Tiranë: botim i Qendrës së Botimeve Zyrtare, https://qbz.gov.al/preview/ba544cc3-052a4e95-8537-0c7c4547c1c8

[26] QBZ (2018), 'Përmbledhëse Legjislacioni për Vetqeverisjes Vendore', Tiranë: botim i Qendrës së Botimeve Zyrtare, https://qbz.gov.al/preview/1ec6b252-f349-4746-af50-22980461712c

[27] QBZ (2019), 'Përmbledhëse Legjislacioni për Urbanistikën', Tiranë: botim i Qendrës së Botimeve Zyrtare, https://qbz.gov.al/preview/35686c1e-88ba46c4-948e-30d619f28c98

[28] Spencer H., (2005), 'Njeriu Kundër shtetit', Tiranë: shtëpia botuese Dita 2000, përkthim nga Bashkim Shehu, 2005

[29] United Nation, Economic Commission for Europe, [UNECE], (2008), 'Spatial Planning; Key Instrument for Development and Effective Governance with Special Reference to Countries in Transition', United Nations Publication, Printed at United Nations, Geneva, Switzerland

[30] United Nation, [UN], (1976), 'The Vancouver Declaration On Human Settlements', from the report of Habitat: United Nations Conference on Human Settlements Vancouver, Canada, 31 May to 11 June 1976 https://mirror.unhabitat.org/downloads/docs/The_Vancouver_Decl aration.pdf

[31] World Planners Congress, [WPC], (2006), 'Vancouver Declaration', Vancouver, Canada http://www.globalplannersnetwork.org/wpcontent/uploads/2017/08/WPC-declaration-2006-updated-June-2017.pdf 